\title{
Scleral buckle is good option for treatment of uncomplicated retinal detachment
}

\author{
Introflexão escleral é boa opção para tratamento \\ de descolamento de retina não complicado
}

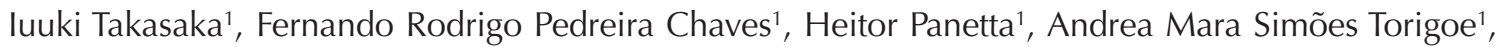
Valdir Balarin Silva', Rodrigo Pessoa Cavalcanti Lira ${ }^{1}$

\begin{abstract}
Objetive: To describe the reattachment rate and visual acuity results of patients with uncomplicated rhegmatogenous retinal detachment who underwent segmental scleral buckle surgery. Methods: Prospective case series of 100 patients with visual loss or symptoms (floaters and photopsia) of less than 30 days' duration scheduled for surgery. No patient had a retinal break greater than $30^{\circ}$, a retinal detachment larger than 2 quadrants or proliferative vitreoretinopathy. Results: The 1-week, 1-month, and 6-month anatomical success rates were $93 \%, 100 \%$, and $100 \%$, respectively. Seven patients underwent one additional retinal detachment surgery (pars plan vitrectomy) after primary failure at 1-week follow-up. The preoperative, 1-month, and 6-month best correct visual acuity were 20/100, 20/80, and 20/50, respectively. The postoperative complications were: eyelid edema in 10\% of the patients, transient ocular hypertension in $5 \%$, macular pucker in $3 \%$, transient diplopia in $3 \%$, and hyphema $(<0.5 \mathrm{~mm})$ in $1 \%$. Conclusion: In patients with uncomplicated retinal detachment, segmental scleral buckle showed a very good anatomical and functional success, with a few number of major complications.
\end{abstract}

Keywords: Scleral buckling; Retinal detachment; Cryotherapy; Vitreoretinopathy proliferative

\begin{abstract}
RESUMO
Objetivo: Descrever a taxa de reaplicação e os resultados da acuidade visual dos pacientes com descolamento de retina regmatogênico simples que se submeteram à cirurgia de introflexão escleral segmentar. Métodos: Uma série de casos prospectivo de 100 pacientes com perda visual ou sintomas (floaters e fotopsia), com duração inferior a 30 dias, agendados para a cirurgia. Nenhum paciente apresentou uma ruptura da retina superior a $30^{\circ}$, um descolamento de retina maior que 2 quadrantes ou vitreorretinopatia. Resultados: As taxas de sucesso anatômico em 1 semana, 1 mês e 6 meses foram de $93 \%, 100 \%$ e $100 \%$, respectivamente. Sete pacientes foram submetidos à cirurgia de descolamento de retina adicional (vitrectomia via pars plana) após falha primária em uma semana de seguimento. A melhor acuidade visual pré-operatória, 1 mês, e de 6 meses pós-operatório foram 20/100, 20/80 e 20/50, respectivamente. As complicações pós-operatórias foram: edema palpebral em $10 \%$ dos pacientes, a hipertensão ocular transitória em $5 \%$, pucker macular em 3\%, diplopia transiente em 3\%, e hifema $(<0,5 \mathrm{~mm})$ em $1 \%$. Conclusão: Em pacientes com descolamento da retina sem complicações, a cirurgia de introflexão segmentar escleral mostrou um sucesso anatômico e funcional muito bom, com um número menor de complicações maiores.

Descritores: Recurvamento da esclera; Descolamento de retina; Crioterapia; Vitreorretinopatia proliferativa
\end{abstract}

'Departament of Ophthalmology, Universidade Estadual de Campinas UNICAMP - Campinas (SP), Brazil.

Study carried out at Departament of Ophthalmology - Universidade Estadual de Campinas (UNICAMP) - Campinas (SP), Brazil.

The authors declare no conflicts of interest

Recebido para publicação em: 22/9/2011 - Aceito para publicação em: 2/3/2012

Rev Bras Oftalmol. 2012; 71 (6): 377-9 


\section{INTRODUCTION}

$\mathbf{T}$

The rhegmatogenous is the most common type retinal detachment (RD) and is caused by a full-thickness break in the retina. As the vitreous becomes more liquefied with age, a posterior vitreous detachment (PVD) occurs. However, in certain eyes, strong vitreoretinal adhesions are present, and the occurrence of a PVD can lead to a retinal tear formation. Fluid from the liquefied vitreous can seep under the tear, leading to fluid accumulation with the separation of the neurosensory retina from the underlying retinal pigment epithelium. The use of scleral buckles in conjunction with chorioretinal adhesions around retinal breaks forms the basis of therapy for many uncomplicated $\mathrm{RD}^{(1-6)}$

The main purpose of this prospective case series was to describe the reattachment rate and visual acuity results of patients with uncomplicated rhegmatogenous retinal detachment who underwent segmental scleral buckle surgery.

\section{MethodS}

A total of 100 patients were recruited to a prospective case series from a private clinic in Recife, Brazil. Ethics committee approval was obtained, and all participants gave informed consent (CONEP 0147.0.172.000-06).

Inclusion criteria were primary rhegmatogenous RD with a single peripheral retinal break. All patients had phakia, were 18 years or older, had partial or total PVD, and had visual loss or symptoms (floaters and photopsia) of less than 30 days' duration. No patient had a retinal break greater than $30^{\circ}$ or RRD larger than 2 quadrants. Also, there was no history of uveitis or infectious retinopathy, proliferative vitreoretinopathy, macular disease, glaucoma, hemoglobinopathy, diabetic retinopathy, trauma or previous vitreoretinal surgery.

The surgical procedure included peribulbar anesthesia with $8 \mathrm{~mL}$ of $0.75 \%$ ropivacaine hydrochloride, drainage of subretinal fluid, and the placement of the segmental buckle in all patients. Cryopexy or laserpexy was performed around the break.

Preoperative data were collected by means of a medical history form completed by the physician at the time of preoperative medical examination. Postoperative best-corrected visual acuity, assessment of retinal reattachment, medical events, and treatments were recorded on a standardized form by a member of the medical staff. The outcomes were the 1-week, 1month and 6-month reattachment rates, best-corrected visual acuity (with Early Treatment Diabetic Retinopathy Study charts), rate of subsequent operations, and postoperative complications.

\section{RESULTS}

We enrolled 100 eyes of 100 patients scheduled to undergo scleral buckle surgery. The demographic data were mean age 53 $(\mathrm{SD}=12)$ years old, mean symptoms duration of $12(\mathrm{SD}=9)$ days, $54(54 \%)$ males, and $72(72 \%)$ patients with RD affecting macula.

The 1-week, 1-month, and 6-month anatomical success rates were $93 \%$ (93 patients), $100 \%$, and $100 \%$, respectively. Seven (7\%) patients underwent one additional retinal detachment surgery (pars plan vitrectomy) after primary failure at 1 -week follow-up.

The preoperative, 1-month, and 6-month best correct visual acuity were 20/100, 20/80, and 20/50, respectively (Figure 1 and Table 1).

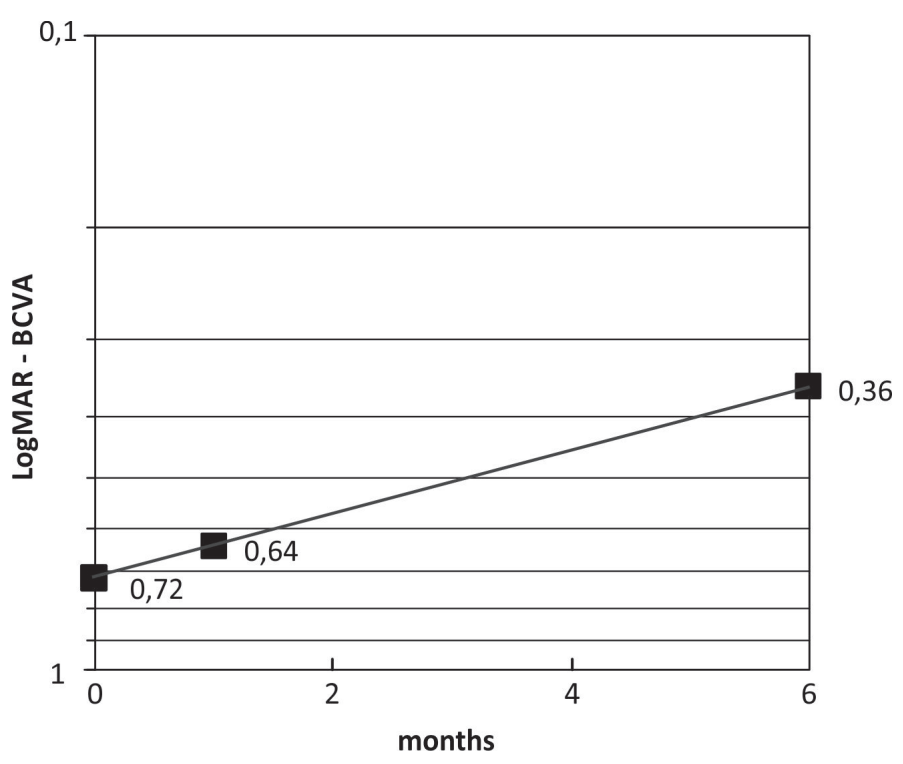

Figure 1: Progression of visual acuity after segmental scleral buckle surgery

Table 1

Mean BCVA in segmental scleral buckle surgery

\begin{tabular}{lccl}
\hline \multicolumn{1}{c}{ BCVA } & Letters & LogMar & Snellen \\
\hline Preoperative & 52 & 0.72 & $20 / 100$ \\
1 - month & 56 & 0.64 & $20 / 80$ \\
6 - months & 70 & 0.36 & $20 / 50$ \\
\hline
\end{tabular}

BCVA - best correct visual acuity with early treatment diabetes retinopathy study charts

The postoperative complications were: eyelid edema in $10 \%$ of the patients (this patients received cryopexy), transient ocular hypertension (duration $<7$ days) in $5 \%$, macular pucker (these patients had RD affecting macula before surgery) in 3\%, transient diplopia (duration $<30$ days) in $3 \%$, hyphema $(<0.5 \mathrm{~mm})$ in $1 \%$.

\section{Discussion}

A primary anatomical success rate of $93 \%$ was observed, which is comparable to data from previous nationals and internationals studies of scleral buckle surgery ranging from $81 \%$ to $94,7 \%^{(1,3,4,6,7)}$.

The visual acuity improved between the 1-month and 6months postoperative examination. This result confirms data from previous studies ${ }^{(1-4,6,8)}$.

Scleral buckling procedures have been used as a treatment for primary RRD for about 70 years. These procedures are still effective and widely adopted even today, the other current option to treat retinal detachment is vitrectomy but the reattachment rate and visual acuity results are not superior to scleral buckle ${ }^{(9,10)}$. Most of the adverse events in this study related to segmental scleral buckle were minor postoperative complications, mainly eyelid edema ${ }^{(9,11)}$

It still is as good and a cheaper option to vitrectomy for a wide variety of RD. Furthermore, this is only an issue if both therapies are affordable, but many patients do not have access to vitrectomy surgery and for many surgeons scleral buckle 
remains the first choice for RD in select situations, as in case of incomplete PVD ${ }^{(10,12)}$.

However, the high anatomical success rates found in this study must be analyzed with caution because the treated patients had primary RD and lacked high-risk characteristics, such as cataract surgery, complete PVD, retinal break greater than $30^{\circ}$, or presence of proliferative vitreoretinopathy.

The results of this study suggest that in patients with uncomplicated retinal detachment, segmental scleral buckle provide satisfactory anatomical and functional success. It is not time to forget scleral buckle surgery.

\section{ReFERENCES}

1. Lincoff HA, McLean JM. Cryosurgical treatment of retinal detachment. II. Am J Ophthalmol. 1966;61(5 Pt 2):1227-34.

2. Yoon YH, Marmor MF. Rapid enhancement of retinal adhesion by laser photocoagulation. Ophthalmology. 1988;95(10):1385-8.

3. Pastor JC, Fernández I, Rodríguez de la Rúa E, Coco R, SanabriaRuiz Colmenares MR, Sánchez-Chicharro D, et al. Surgical outcomes for primary rhegmatogenous retinal detachments in phakic and pseudophakic patients: the Retina 1 Project-report 2. Br J Ophthalmol. 2008;92(3):378-82.

4. Mahdizadeh M, Masoumpour M, Ashraf H. Anatomical retinal reattachment after scleral buckling with and without retinopexy: a pilot study. Acta Ophthalmol. 2008;86(3):297-301.

5. La Heij EC, Derhaag PF, Hendrikse F. Results of scleral buckling operations in primary rhegmatogenous retinal detachment. Doc Ophthalmol. 2000;100(1):17-25.
6. Ikuno PR, Ciconelli CRO. Laserterapia no pós-operatório da cirurgia de descolamento de retina com introflexão escleral. Rev Bras Oftalmol. 1994;53(3):33-7.

7. Fortes Filho JB, Bonomo PP, Gama AJC, Lubisco Filho H, Marcon IM. Utilização do implante de silicone sólido em forma de cunha em cirurgias do descolamento da retina associado à presença de "boca de peixe". Arq Bras Oftalmol. 1989;52(5):153-8.

8. Goldhardt R, Corrêa ZMS, Eichenberg MC, Marcon IM. Retinopexia com introflexão escleral em serviço de ensino de Oftalmologia. Rev Bras Oftalmol. 2001;60(2):126-31.

9. Sabates NR, Sabates FN, Sabates R, Lee KY, Ziemianski MC. Macular changes after retinal detachment surgery. Am J Ophthalmol. 1989;108(1):22-9.

10. Williams GA, Aaberg Jr TM. Techniques of scleral buckling. In: Ryan SJ, editor. Retina. 4th ed. 2006.St Louis: Mosby; p. 2042-50.

11. Lobes LA Jr, Burton TC. The incidence of macular pucker after retinal detachment surgery. Am J Ophthalmol. 1978;85(1):72-7.

12. McLeod D. Is it time to call time on the scleral buckle? Br J Ophthalmol. 2004;88(11):1357-9.

\section{Autor correspondente:}

Rodrigo Pessoa Cavalcanti Lira, MD,

Department of Ophthalmology, State University of Campinas

Rua Irmã Maria David 200, apto. 1302, CEP 52061-070

Recife, PE Brazil

Email: rodrigopclira@hotmail.com 